Acta vet. scand. $1968,9,183-198$.

From the Department of Pharmacology and Toxicology, Royal Veterinary and Agricultural College, Copenhagen, Denmark.

\title{
RENAL CLEARANCES IN PIGS
}

INULIN, ENDOGENOUS CREATININE, UREA, PARA-AMINOHIPPURIC ACID, SODIUM, POTASSIUM, AND CHLORIDE

By

N. Gyrd-Hansen

The increasing interest during recent years in the use of pigs in experimental biological research has necessitated a deeper knowledge of the basic function of a number of organs, including the kidneys. The first report on the kidney function of pigs appeared in 1953 when Dalgaard-Mikkelsen et al. described the renal clearance of inulin, sulphadimidine and sulphathiazole. Subsequently, Munsick et al. (1958) provided data from experiments on 4 "miniature" pigs, while Vogel (1959a, b) and Ketz $(1960 a, b)$ described the results of classical kidney function tests on sucking pigs and young pigs.

The aim of the present work was to establish normal values for renal clearance in Danish Landrace pigs of the ages 3 to 8 months.

\section{MATERIAL AND METHODS}

The examinations were carried out on 31 clinically healthy female pigs of Danish Landrace, weighing from 28 to $123 \mathrm{~kg}$. All the animals were fed during the whole period with a commercial fodder mixture consisting of $75 \%$ barley, $6 \%$ oats, $10 \%$ soy meal, $5 \%$ skimmed milk powder, $3 \%$ meat- and bonemeal, $0.2 \%$ mixture of vitamins $\mathrm{A}, \mathrm{B}, \mathrm{D}$ and $\mathrm{E}$, and $0.8 \%$ mineral salt, consisting of $60 \%$ calcium carbonate, $20 \%$ dicalcium phosphate, $15 \%$ sodium chloride, $3.5 \%$ copper sulphate, $0.75 \%$ zinc car- 
bonate, $0.625 \%$ manganese oxide and $0.125 \%$ cobalt sulphate. When the pigs were killed, the kidneys and the urinary system were examined macroscopically and all were found to be normal.

\section{Clearances}

The experiments were performed on unanaesthetized animals which had free access to water before commencement of the study. During the experiments the pigs were laid on their abdomens on a slatted table to which they were fastened by means of straps over the neck and back.

Blood specimens were taken at 20 -min. intervals through a thin plastic catheter (Intracath $\left.{ }^{\circledR}\right)$ inserted into a vein in the right ear. Clotting was prevented with heparin, and the blood was centrifuged within $2 \mathrm{hrs}$. Plasma was used for analysis. The urine was collected quantitatively through a balloon catheter (Rüsch no. 14, $30 \mathrm{ml}$ ) inserted into the bladder. This was emptied at 20-min. intervals and, in order to ensure complete evacuation, the bladder was washed with $30 \mathrm{ml}$ of distilled water. Each experiment consisted of at least 3 periods.

In the experiments where continuous intravenous infusion (Sigmamotor ${ }^{\circledR}$ infusion pump) of inulin solution or of a solution containing both inulin and PAH (para-aminohippuric acid) was carried out, this was done through a plastic catheter inserted into a vein in the left ear. The priming dose of inulin was about $40 \mathrm{mg} / \mathrm{kg}$ and of PAH about $11 \mathrm{mg} / \mathrm{kg}$, both dissolved in $50 \mathrm{ml}$ of distilled water. After priming, the inulin and $\mathrm{PAH}$, dissolved in a $0.6 \%$ sodium chloride solution, were infused at a rate of $3 \mathrm{ml}$ per min. (inulin $0.3 \mathrm{mg} / \mathrm{kg} / \mathrm{min}$. and PAH $0.2 \mathrm{mg} / \mathrm{kg} / \mathrm{min}$.). The first experimental period was commenced $30 \mathrm{~min}$. after infusion of the priming dose.

The analytical methods used were as follows: Inulin: Brun (1946), endogenous creatinine: Bonsnes \& Taussky (1945), PAH: Bratton \& Marshall (1939), urea: Conway (1950), chloride: Schales \& Schales (1941). Potassium and sodium were determined by flame photometer (Beckman Direct Reading Flame Photometer). All the plasma concentrations found were calculated to correspond to the values at the water phase of the plasma, the content of dry matter in plasma being considered to be $8 \%$. The haematocrit values were determined in micro-haematocrit tubes after centrifugation in a MSE Micro Haematocrit Centrifuge for $15 \mathrm{~min}$. at 4500 r.p.m. 
Binding of PAH to the plasma proteins was examined by ultrafiltration through a cellophane membrane as described by Poulsen (1956). The cellophane membrane used is "Kalle" dialysing tube, diameter $32 \mathrm{~mm}$, pore size $20-80 \AA$, which should permit molecules with a molecular weight up to 5000 to pass through.

\section{RESULTS}

Relationship between body weight and kidney weight. Fig. 1 shows the body weight immediately before death in relation to the weight of the 2 decapsulated and bloodless kidneys. The ma-

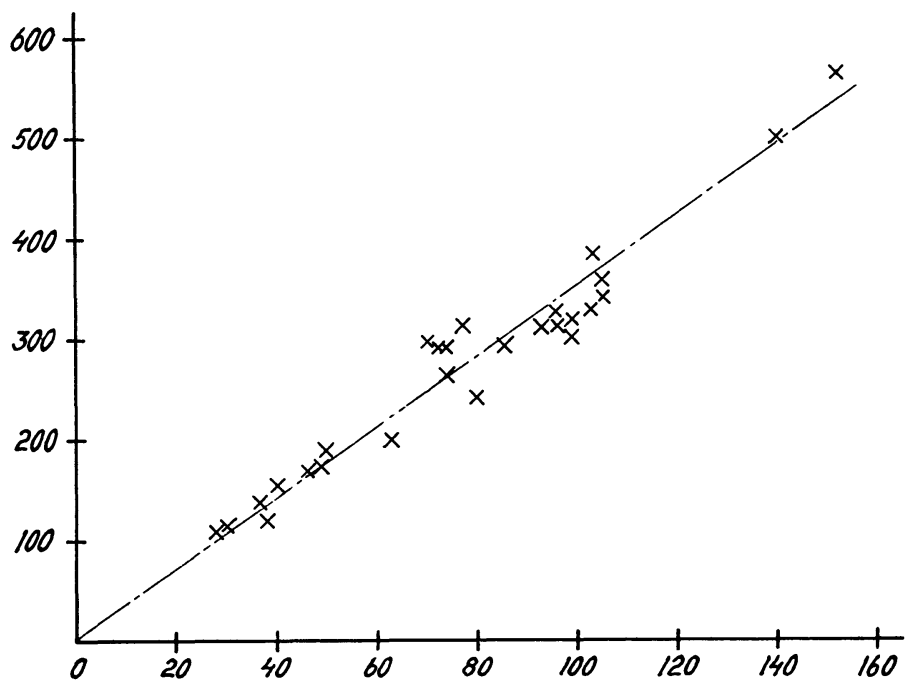

Figur e 1. Relation between kidney weight and body weight. Ordinate: Kidney weight in g. Abscissa: Body weight in $\mathrm{kg}$.

terial consists of kidneys from 27 pigs weighing between 28 and $152 \mathrm{~kg}$. The curve shows that there is proportionality between body weight and kidney weight throughout the whole period. The average kidney weight is $0.36 \%$ of the body weight (range 0.31 to $0.43 \%$ ).

Effect on inulin clearance of various plasma concentrations. In order to examine whether the clearance of inulin was affected by variations in the inulin concentrations in plasma, the priming dose was increased from $16 \mathrm{mg} / \mathrm{kg}$ to $500 \mathrm{mg} / \mathrm{kg}$ and the maintenance dose from 0.1 to $5 \mathrm{mg} / \mathrm{kg} / \mathrm{min}$. in experiments on 4 pigs, 


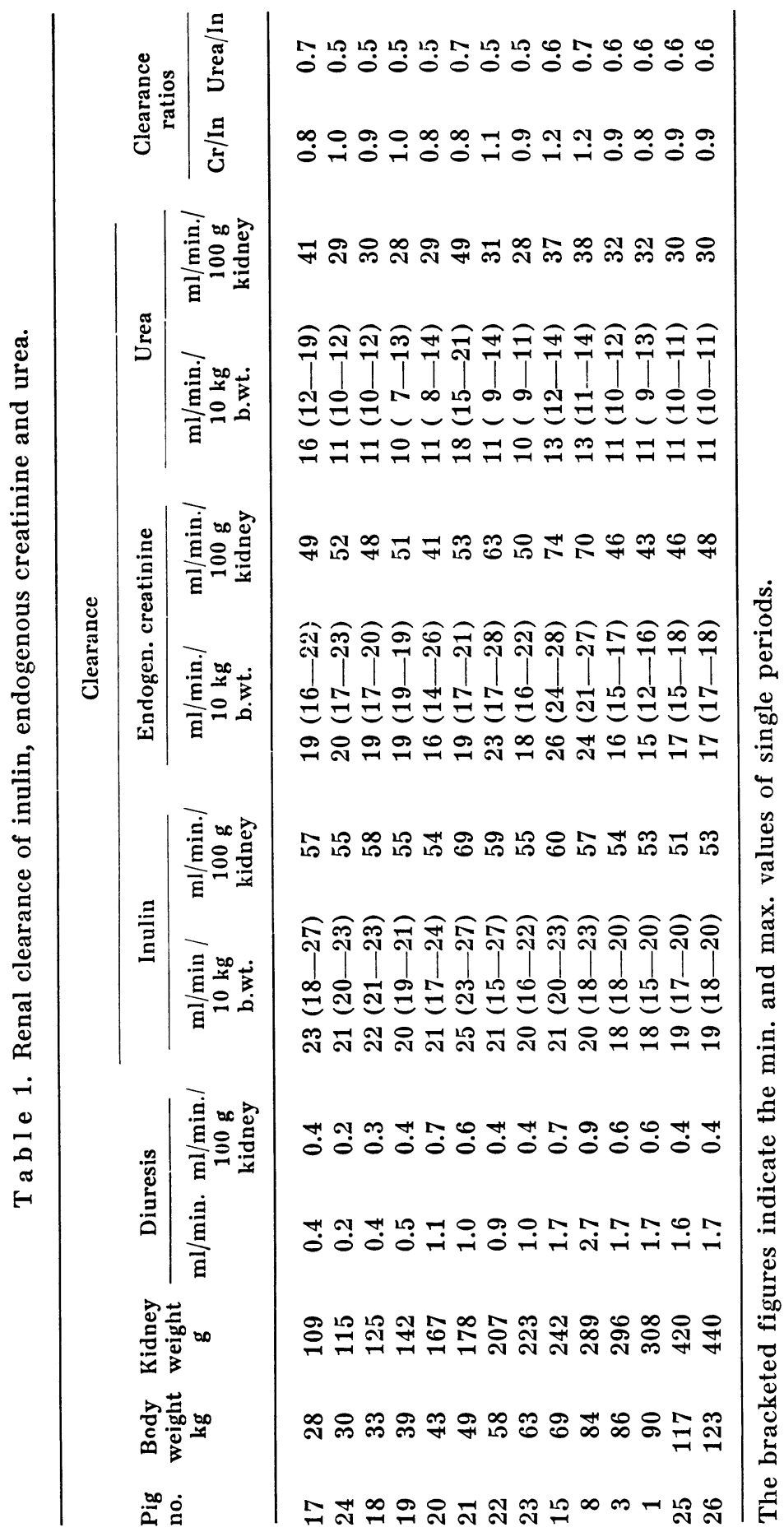




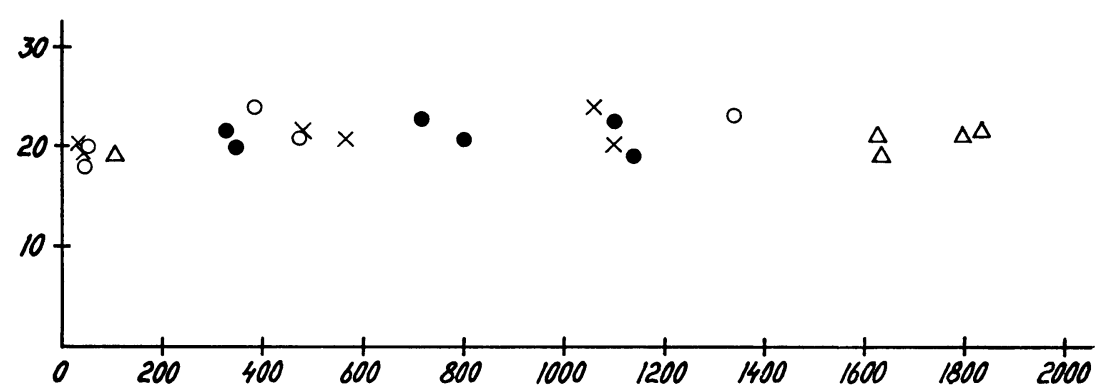

$\mathrm{F}$ i g u r e 2. Inulin clearance at different concentrations of inulin in plasma.

Ordinate: Clearance $\mathrm{ml} / \mathrm{min} . / 10 \mathrm{~kg}$ b. wt.

Abscissa: Concentrations of inulin in plasma $\mu \mathrm{g} / \mathrm{ml}$.

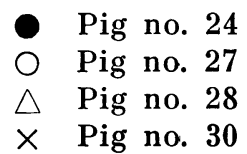

thereby obtaining inulin concentrations in plasma varying from 40 to $1900 \mu \mathrm{g} / \mathrm{ml}$. The urine flow varied only slightly in each experiment. The results are given in Fig. 2, which shows that the clearance per $10 \mathrm{~kg}$ body weight of the individual pigs was constant within the concentration range mentioned.

Effect on inulin clearance of variations in diuresis. The influence of the rate of urine flow on inulin clearance was examined in experiments on 4 pigs. Urine flow was constant during each period but varied in the experiments from 0.07 to $1.91 \mathrm{ml} / \mathrm{min}$./ $10 \mathrm{~kg}$ by giving water at body temperature per os and infusion of PAH solution. The inulin concentration in plasma was constant $( \pm 10 \%)$ in these experiments. It was found that the clearance of inulin was independent of the degree of diuresis (Fig. 3).

Clearance of inulin, endogenous creatinine and urea. Table 1 shows the results of 14 experiments in which clearances of inulin, endogenous creatinine and urea were determined simultaneously. The concentrations of the test substances in plasma were constant $( \pm 10 \%)$ in each experiment. The lowest and highest inulin concentrations were $108 \mu \mathrm{g} / \mathrm{ml}$ and $201 \mu \mathrm{g} / \mathrm{ml}$, respectively, while the content of urea and creatinine in plasma varied between 241 and $588 \mu \mathrm{g} / \mathrm{ml}$ and between 7 and $19 \mu \mathrm{g} / \mathrm{ml}$, respectively. Urine flow varied from 0.2 to $2.7 \mathrm{ml} / \mathrm{min}$. It will be seen from the table that the clearances of inulin, creatinine and urea calculated per $10 \mathrm{~kg}$ body weight and $100 \mathrm{~g}$ kidney were constant in pigs weigh- 


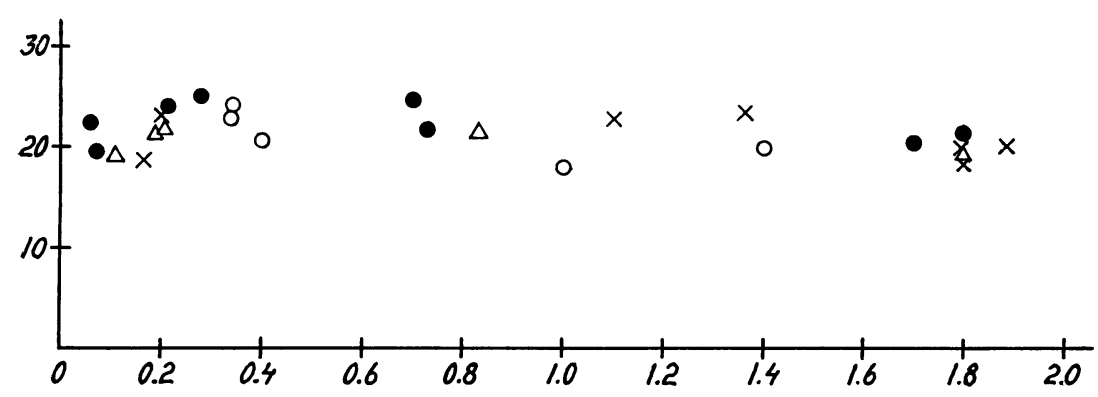

$\mathrm{Fig} \mathrm{u} \mathrm{r} \mathrm{e} \mathrm{3.} \mathrm{Inulin} \mathrm{clearance} \mathrm{at} \mathrm{different} \mathrm{diuresis.}$

Ordinate: Clearance $\mathrm{ml} / \mathrm{min} . / 10 \mathrm{~kg}$ b. wt.

Abscissa: Diuresis $\mathrm{ml} / \mathrm{min}$.

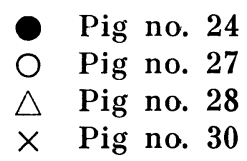

ing 28 to $123 \mathrm{~kg}$. In 8 cases calculation of clearance per $100 \mathrm{~g}$ kidney was made on the basis of the actual kidney weight determined after death, while in the other 6 cases it was made by means of a kidney weight calculated as $0.36 \%$ of the body weight.

The calculated clearance ratios for endogenous creatinine/ inulin and urea/inulin are shown in the last 2 columns of the table. It will be seen that in the majority of the experiments there is good correlation between inulin and endogenous creatinine clearance, and on the basis of calculation of the averages, there is full agreement between these 2 methods for determination of the filtration clearance. Urea clearance was quite constant at $60 \%$ of the filtration clearance, and it will be seen from the table that urine flow during the experiments varied from 0.2 to $2.7 \mathrm{ml} / \mathrm{min}$. $(0.07$ to $0.32 \mathrm{ml} / \mathrm{min} . / 10 \mathrm{~kg}$ body weight $)$ without having any effect on the urea clearance.

Clearance of para-aminohippuric acid. The clearance of paraaminohippuric acid (PAH) was determined on 8 pigs. The PAH concentration in plasma during these experiments was between 15 and $18 \mu \mathrm{g} / \mathrm{ml}$. No binding of PAH to the plasma proteins could be demonstrated by ultrafiltration through a cellophane membrane.

As will be seen from Table 2, the clearance of PAH varies from 52 to $84 \mathrm{ml} / \mathrm{min}$. $/ 10 \mathrm{~kg}$ body weight or from 146 to $229 \mathrm{ml} /$ min./100 g kidney (in average $64 \mathrm{ml} / \mathrm{min} . / 10 \mathrm{~kg}$ body weight or $174 \mathrm{ml} / \mathrm{min} . / 100 \mathrm{~g}$ kidney). Since the inulin clearance was deter- 
T a b l e 2. Clearance of para-aminohippuric acid and the filtration fraction.

\begin{tabular}{lcccccc}
\hline $\begin{array}{l}\text { Pig } \\
\text { no. }\end{array}$ & $\begin{array}{c}\text { Body } \\
\text { weight } \\
\text { kg }\end{array}$ & $\begin{array}{c}\text { Diuresis } \\
\text { ml/min. }\end{array}$ & $\begin{array}{c}\text { Inulin } \\
\text { clearance } \\
\text { ml/min./ } \\
\text { 10 kg b.wt. }\end{array}$ & $\begin{array}{c}\text { PAH } \\
\text { clearance } \\
\text { ml/min./ } \\
10 \text { kg b.wt.*) }\end{array}$ & $\begin{array}{c}\text { PAH } \\
\text { clearance } \\
\text { ml/min./ } \\
100 \text { g } \\
\text { kidney**) }\end{array}$ & $\begin{array}{c}\text { Filtration } \\
\text { fraction } \\
\text { C }_{\text {In }} / \mathrm{C}_{\text {PAH }}\end{array}$ \\
\hline 24 & 30 & 0.2 & 21 & $56(52-60)$ & 146 & 0.37 \\
19 & 39 & 0.5 & 20 & $84(72-92)$ & 229 & 0.24 \\
20 & 43 & 1.1 & 21 & $59(52-72)$ & 152 & 0.35 \\
21 & 49 & 1.0 & 25 & $79(74-87)$ & 216 & 0.32 \\
22 & 58 & 0.9 & 21 & $69(56-86)$ & 194 & 0.31 \\
23 & 63 & 1.0 & 20 & $53(47-60)$ & 152 & 0.36 \\
25 & 117 & 1.6 & 19 & $58(54-63)$ & 158 & 0.32 \\
26 & 123 & 1.7 & 19 & $52(48-58)$ & 146 & 0.37 \\
\hline
\end{tabular}

*) The bracketed figures indicate the min. and max. values of single periods.

* *) Calculated from the relative kidney weight $0.36 \%$.

mined at the same time, it was possible to calculate the part of the plasma - the filtration fraction - which is filtered through the glomeruli $\left(\mathrm{C}_{\mathrm{In}_{\mathrm{n}}} / \mathrm{C}_{\mathrm{PAH}}\right)$. Table 2 shows that the average filtration fraction was 0.33 , varying from 0.24 to 0.37 .

Maximal tubular PAH excretion. The maximal excretion ( Tm) of PAH was determined in 10 experiments on 7 pigs during loading with PAH. In 7 cases the experiments started with the determination of PAH clearance in 3 periods of $20 \mathrm{~min}$. with a small PAH concentration in plasma $(10-24 \mu \mathrm{g} / \mathrm{ml})$. In the loading experiments the priming dose was about $500 \mathrm{mg} / \mathrm{kg}$ and the maintenance dose about $5 \mathrm{mg} / \mathrm{kg} / \mathrm{min}$., thereby obtaining high $\mathrm{PAH}$ concentrations in plasma (Table 3 ). The experiments that commenced with determination of $\mathrm{C}_{\mathrm{PAH}}$ with low $\mathrm{PAH}$ concentration in plasma showed that the PAH clearance in the same animal was considerably less during loading with PAH than with a PAH content in plasma of about $20 \mu \mathrm{g} / \mathrm{ml}$.

On the basis of PAH clearance $\left(\mathrm{C}_{\mathrm{PAH}}\right)$ during loading with $\mathrm{PAH}$ and the inulin clearance $\left(\mathrm{C}_{\mathrm{In}}\right)$ measured simultaneously, the maximal tubular excretion was calculated from the formula

$$
\mathbf{T m}=\left(\mathrm{C}_{\mathbf{P A H}}-\mathrm{C}_{\text {In }}\right) \times \mathbf{P}_{\mathbf{P A H}}
$$

where $\mathbf{P}_{\mathrm{PAH}}$ is the $\mathrm{PAH}$ concentration in plasma. As will be seen from the last column of Table 3, the calculated $\mathrm{Tm}$ values vary from 17 to $37 \mathrm{mg} / \mathrm{min} . / 10 \mathrm{~kg}$ body weight or from 47 to $100 \mathrm{mg} /$ 
T a ble 3. Clearance and maximal tubular excretion (Tm) of paraaminohippuric acid $^{*}$ ).

\begin{tabular}{|c|c|c|c|c|c|c|}
\hline $\begin{array}{l}\text { Pig } \\
\text { no. }\end{array}$ & $\begin{array}{c}\text { Body } \\
\text { weight } \\
\text { kg }\end{array}$ & $\begin{array}{c}\text { Plasma } \\
\text { concentıation } \\
\text { of PAH } \\
\mu \mathrm{g} / \mathrm{ml}\end{array}$ & $\begin{array}{c}\text { PAH } \\
\text { clearance } \\
\text { ml } / \text { min / } \\
10 \text { kg b.wt. }\end{array}$ & $\begin{array}{c}\text { Inulin } \\
\text { clearance } \\
\text { ml min./ } \\
10 \mathrm{~kg} \mathrm{b.wt}\end{array}$ & $\begin{array}{c}\mathrm{Tm} \\
\mathrm{mg} / \mathrm{min} . / \\
10 \mathrm{~kg} \text { b wt. }\end{array}$ & $\begin{array}{c}\text { Tm } \\
\text { mg/min./ } \\
100 \mathrm{~g} \\
\text { kidney**) }\end{array}$ \\
\hline 24 & 30 & 1340 & 37 & 22 & 20 & 49 \\
\hline 27 & 32 & 585 & 61 & 22 & 22 & 61 \\
\hline 28 & 40 & 1340 & 32 & 16 & 22 & 61 \\
\hline 29 & 47 & 1207 & 47 & 21 & 31 & 86 \\
\hline 30 & 61 & 931 & 63 & 23 & 37 & 100 \\
\hline 25 & 79 & 1426 & 30 & 16 & 20 & 56 \\
\hline 26 & 81 & 1503 & 24 & 13 & 17 & 47 \\
\hline 26 & 100 & 1545 & 34 & 18 & 24 & 67 \\
\hline 25 & 117 & 1673 & 30 & 17 & 23 & 64 \\
\hline 26 & 123 & 1766 & 25 & 14 & 19 & 53 \\
\hline
\end{tabular}

*) The figures indicate the average for 3 periods.

**) Calculated from the relative kidney weight $0.36 \%$.

min./100 g kidney, with an average of $23 \mathrm{mg} / \mathrm{min} . / 10 \mathrm{~kg}$ or 64 $\mathrm{mg} / \mathrm{min}$./100 g kidney.

Extraction percentage for PAH. The experiments were carried out on pigs anaesthetized with phencyclidinum NFN $(1.5 \mathrm{mg} / \mathrm{kg}$ intramuscularly) combined with inhalation of halothanum NFN. A solution of PAH was infused during the whole experiment through a catheter inserted into a vein in the left ear. The priming dose was $35 \mathrm{mg} / \mathrm{kg}$ and the maintenance dose $0.6 \mathrm{mg} / \mathrm{kg} / \mathrm{min}$. A plastic catheter was led through the femoral artery along the aorta to the source of the renal artery, from which site arterial blood was taken. Blood from the right vena renalis was taken through a plastic catheter inserted into the vein after laparotomy.

T a b l e 4. The renal extraction of para-aminohippuric acid.

\begin{tabular}{ccccc}
\hline & & \multicolumn{2}{c}{ Concentration of PAH in plasma from } & \\
\cline { 3 - 4 } $\begin{array}{c}\text { Pig } \\
\text { no. }\end{array}$ & $\begin{array}{c}\text { Body } \\
\text { weight } \\
\text { kg }\end{array}$ & $\begin{array}{c}\text { A. renal. } \\
\mu \mathrm{g} / \mathrm{ml}\end{array}$ & $\begin{array}{c}\text { V. renal. } \\
\mu \mathrm{g} / \mathrm{ml}\end{array}$ & $\begin{array}{c}\text { Extraction } \\
\text { of PAH } \\
\text { \% }\end{array}$ \\
\hline 27 & 45 & 60.0 & 6.7 & 89 \\
28 & 50 & 12.3 & 2.4 & 80 \\
29 & 55 & 54.6 & 5.8 & 89 \\
30 & 61 & 102.5 & 8.8 & 91 \\
31 & 80 & 53.4 & 8.1 & 85 \\
\hline
\end{tabular}


The arterial blood pressure was measured continuously by means of a Statham ${ }^{\circledR}$ transducer P23AA.

The extraction (E) of $\mathrm{PAH}$ in one passage through the kidney was estimated in 5 pigs; the results (42 observations) are given in Table 4. As will se seen from the table, the concentration of PAH in plasma taken from the vena renalis was much less than in plasma from the arterial blood. The percentage extraction was constant at plasma PAH levels varying from 12 to $103 \mu \mathrm{g} / \mathrm{ml}$ and was in average $87 \%$. The arterial blood pressure was between $80 / 60$ and $165 / 110 \mathrm{~mm} \mathrm{Hg}$ during the experiments.

Renal blood flow. When PAH clearance and the extraction percentage $(\mathrm{E} \%)$ are known, the total renal plasma flow ( $\left.\mathrm{RPF}_{\text {total }}\right)$ can be calculated from the formula

$$
\mathrm{RPF}_{\text {(total) }}=\mathrm{C}_{\mathrm{PAH}} \times \frac{100}{\mathrm{E}^{\%} / 0} \times \frac{100}{92}
$$

where, by means of the last factor, conversion can be made from plasma water flow to plasma flow. On the basis of the plasma flow and the haematocrit values (shown in Table 5), the total renal blood flow can be calculated from the formula (Pitts 1965)

$$
\mathrm{RBF}_{(\text {total })}=\frac{\mathrm{RPF}_{(\text {total })} \times 100}{100-\text { haematocrit } \%}
$$

The last 3 columns of Table 5 show the renal blood flow, the blood flow per $10 \mathrm{~kg}$ body weight and per $100 \mathrm{~g}$ kidney for each

T a b l e 5. Clearance of para-aminohippuric acid, total renal plasma

\begin{tabular}{|c|c|c|c|c|c|c|c|c|}
\hline \multirow{2}{*}{$\begin{array}{l}\text { Pig } \\
\text { no. }\end{array}$} & \multirow{2}{*}{$\begin{array}{l}\text { Body } \\
\text { weight } \\
\text { kg }\end{array}$} & \multirow{2}{*}{$\begin{array}{c}\text { Kidney } \\
\text { weight } \\
\text { g }\end{array}$} & \multirow{2}{*}{$\begin{array}{c}\text { Haema- } \\
\text { tocrit } \\
\% \%\end{array}$} & \multirow{2}{*}{$\begin{array}{l}\text { PAH } \\
\text { clearance } \\
\text { ml/min. }\end{array}$} & \multirow{2}{*}{$\begin{array}{c}\text { Total renal } \\
\text { plasma } \\
\text { flow } \\
\mathrm{ml} / \mathrm{min} .\end{array}$} & \multicolumn{3}{|c|}{ Total renal blood flow } \\
\hline & & & & & & $\begin{array}{c}\mathrm{ml} / \\
\text { min. }\end{array}$ & $\begin{array}{l}\mathrm{ml} / \mathrm{min} . / \\
10 \mathrm{~kg} \\
\text { b.wt. }\end{array}$ & $\begin{array}{c}\mathrm{ml} / \mathrm{min} . / \\
100 \mathrm{~g} \\
\text { kidney }\end{array}$ \\
\hline 24 & 30 & 115 & 39 & 168 & 210 & 344 & 115 & 300 \\
\hline 19 & 39 & 142 & 36 & 320 & 400 & 625 & 160 & 440 \\
\hline 20 & 43 & 167 & 42 & 254 & 318 & 548 & 127 & 328 \\
\hline 21 & 49 & 178 & 36 & 384 & 480 & 750 & 153 & 421 \\
\hline 22 & 58 & 207 & 42 & 401 & 501 & 862 & 149 & 416 \\
\hline 23 & 63 & 223 & 42 & 338 & 423 & 729 & 116 & 327 \\
\hline 25 & 117 & 420 & 42 & 681 & 850 & 1467 & 125 & 349 \\
\hline 26 & 123 & 440 & 43 & 642 & 803 & 1409 & 115 & 320 \\
\hline
\end{tabular}
flow and total renal blood flow. 
T a b l e 6. Renal excretion of electrolytes.

\begin{tabular}{|c|c|c|c|c|c|c|c|c|c|}
\hline \multirow{2}{*}{$\begin{array}{l}\text { Pig } \\
\text { no. }\end{array}$} & \multirow{2}{*}{$\begin{array}{c}\text { Body } \\
\text { weight } \\
\text { kg }\end{array}$} & \multirow{2}{*}{$\begin{array}{l}\text { Diuresis } \\
\mathrm{ml} / \mathrm{min} \text {. }\end{array}$} & \multicolumn{4}{|c|}{ Clearance } & \multicolumn{3}{|c|}{ Excretion $\%$} \\
\hline & & & $\begin{array}{c}\text { Inulin } \\
\mathrm{ml} / \mathrm{min} . / \\
10 \mathrm{~kg} \\
\text { b.wt }\end{array}$ & $\begin{array}{c}\text { Sodium } \\
\mathrm{ml} / \mathrm{min} . / \\
10 \mathrm{~kg} \\
\text { b.wt. }\end{array}$ & $\begin{array}{c}\text { Potassium } \\
\mathrm{ml} / \mathrm{min} . / \\
10 \mathrm{~kg} \\
\text { b.wt. }\end{array}$ & $\begin{array}{l}\text { Chloride } \\
\mathrm{ml} / \mathrm{min} . / \\
10 \mathrm{~kg} \\
\text { b.wt. }\end{array}$ & Sodium & $\begin{array}{l}\text { Potas- } \\
\text { sium }\end{array}$ & Chloride \\
\hline 17 & 28 & 0.4 & 23 & 0.009 & 1.2 & 0.02 & 0.04 & 5.2 & 0.09 \\
\hline 24 & 30 & 0.2 & 21 & 0.038 & 1.0 & 0.06 & 0.18 & 5.0 & 0.3 \\
\hline 18 & 33 & 0.4 & 22 & 0.004 & 1.1 & 0.03 & 0.02 & 5.0 & 0.14 \\
\hline 19 & 39 & 0.5 & 20 & 0.002 & 1.5 & 0.07 & 0.01 & 7.5 & 0.35 \\
\hline 20 & 43 & 1.1 & 21 & 0.005 & 1.2 & 0.05 & 0.02 & 5.7 & 0.24 \\
\hline 21 & 49 & 1.0 & 25 & 0.003 & 1.9 & 0.10 & 0.01 & 7.6 & 0.40 \\
\hline 22 & 58 & 0.9 & 21 & 0.004 & 2.5 & 0.03 & 0.02 & 11.9 & 0.14 \\
\hline 23 & 63 & 1.0 & 20 & 0.005 & 2.7 & 0.07 & 0.03 & 13.5 & 0.35 \\
\hline 15 & 69 & 1.7 & 21 & 0.039 & 3.2 & 0.30 & 0.19 & 15.2 & 1.4 \\
\hline 8 & 84 & 2.7 & 20 & 0.007 & 3.8 & 0.20 & 0.04 & 19.0 & 1.0 \\
\hline 3 & 86 & 1.7 & 18 & 0.005 & 2.4 & 0.08 & 0.03 & 13.3 & 0.44 \\
\hline 1 & 90 & 1.7 & 18 & 0.071 & 1.7 & 0.08 & 0.39 & 9.5 & 0.44 \\
\hline 25 & 117 & 1.6 & 19 & 0.025 & 2.0 & 0.03 & 0.13 & 10.5 & 0.16 \\
\hline 26 & 123 & 1.7 & 19 & 0.018 & 0.9 & 0.02 & 0.09 & 4.7 & 0.11 \\
\hline
\end{tabular}

experiment. The average blood flow was $133 \mathrm{ml} / \mathrm{min} . / 10 \mathrm{~kg}$ body weight or $363 \mathrm{ml} / \mathrm{min} . / 100 \mathrm{~g}$ kidney.

Excretion of sodium, potassium and chloride. The renal clearances of sodium, potassium and chloride were determined in 26 pigs, the average values being $0.015,2.8$ and $0.11 \mathrm{ml} / \mathrm{min}$./ $10 \mathrm{~kg}$ body weight, respectively. In 14 of the pigs the electrolytic excretion was measured simultaneously with the inulin clearance; the results are given in Table 6 . The table shows the percentage excretion of sodium, potassium and chloride, and it will be seen that they vary considerably from animal to animal. The chloride clearance was constant in the various experimental periods for the same pigs. However, the sodium and potassium excretion varied somewhat; as regards sodium, the excretion was generally slightly lower at the end of the experiment.

The concentrations of the 3 electrolytes in plasma were quite constant during the experiments. The variations from pig to pig in the content of electrolytes in plasma were negligible, the average content of sodium, potassium and chloride in 26 pigs being $146 \mathrm{mEq} / 1$ (min. 132, max. 158), $4.2 \mathrm{mEq} / 1$ (min. 3.6, max. 4.8) and $109 \mathrm{mEq} / \mathrm{l}$ ( $\mathrm{min} .104$, max. 116) respectively. 


\section{DISCUSSION}

In previous publications on renal clearance of inulin in pigs (Dalgaard-Mikkelsen et al. 1953; Munsick et al. 1958; Vogel $1959 \mathrm{a}, \mathrm{b}$; Ketz 1960a, b) it was assumed that inulin clearance is an indication of the glomerular filtration, as is the case in other animal species and in man (see Poulsen 1957, Knudsen 1959, Pitts 1965). As will be seen from the results of the present study, that assumption is justified, since in pigs also inulin clearance is independent of both plasma concentration and the rate of urine flow. For ease of reference, the clearances of inulin, endogenous creatinine, urea and PAH are assembled in Table 7.

T a ble 7. Average renal clearances in pigs.

\begin{tabular}{|c|c|c|c|}
\hline & \multirow{2}{*}{$\begin{array}{c}\text { Number } \\
\text { of } \\
\text { pigs }\end{array}$} & \multicolumn{2}{|c|}{ Clearance } \\
\hline & & $\begin{array}{c}\mathrm{ml} / \mathrm{min} . / \\
10 \mathrm{~kg} \mathrm{b.wt.}\end{array}$ & $\begin{array}{c}\mathrm{ml} / \mathrm{min} . / \\
100 \mathrm{~g} \text { kidney }\end{array}$ \\
\hline Inulin & 14 & $21(18-25)$ & $56(51-69)$ \\
\hline Endogenous creatinine & 26 & $22(15-34)$ & $61(41-93)$ \\
\hline Urea & 26 & $12(9-18)$ & $34(27-49)$ \\
\hline Para-aminohippuric acid & 8 & $64(52-84)$ & $174(146-229)$ \\
\hline
\end{tabular}

The bracketed figures indicate min. and max. values of single experiments.

Inulin clearance in pigs was $21 \mathrm{ml} / \mathrm{min} . / 10 \mathrm{~kg}$ body weight (18 to 25 ) or $56 \mathrm{ml} / \mathrm{min} . / 100 \mathrm{~g}$ kidney (51 to 69 ), values which remained constant, even though the body weight of the animals varied from 28 to $123 \mathrm{~kg}$. They are identical with those reported by $\operatorname{Ketz}(1960 \mathrm{a}, \mathrm{b})$ for pigs with a body weight of 25 and $50 \mathrm{~kg}$. However, the inulin clearance of $67 \mathrm{ml} / \mathrm{min} . / 100 \mathrm{~g}$ kidney found by Ketz $(1960 \mathrm{~b})$ is somewhat higher than that found in the present material, presumably because the relative kidney weight was less in the pigs used by Ketz. Munsick et al. reported that the inulin clearance for pigs weighing $20 \mathrm{~kg}$ ("miniature" pigs from the Hormel Institute of Austin) was 49 to $53 \mathrm{ml} / \mathrm{min} . / 10 \mathrm{~kg}$ but that this clearance seemed to be very high for animals of that size. In Dalgaard-Mikkelsen et al.'s study it is stated that the inulin clearance of pigs weighing between 15 and $43 \mathrm{~kg}$ is 36.5 $\mathrm{ml} / \mathrm{min} . / 10 \mathrm{~kg}$. Before the start of the experiment the pigs had been given urethane orally as a sedative, and thus the results cannot be compared directly with those obtained in the present study where unanaesthetized pigs were used. 
Such good correlation has been found between clearance of inulin $(21 \mathrm{ml} / \mathrm{min} . / 10 \mathrm{~kg})$ and endogenous creatinine $(22 \mathrm{ml} /$ $\min . / 10 \mathrm{~kg}$ ) that it is justifiable to conclude that endogenous creatinine can be used as basis for calculation of the filtration clearance in pigs. However, it should be stressed that when using endogenous creatinine as basis for calculation, there are greater variations in the clearance than when the calculations are made by means of inulin. Ketz (1960b) found a good correlation between creatinine and inulin clearance in pigs weighing $25 \mathrm{~kg}$, while in animals weighing $50 \mathrm{~kg}$ creatinine clearance was considerably higher than inulin clearance. In Munsick et al.'s work creatinine clearance was constantly lower than inulin clearance. The lack of correlation in these studies may be due to differences in analytical methods. It is particularly the determination of endogenous creatinine in plasma which is difficult and, among other things, very dependent on the method of precipitation. The method used in this study (Bonsnes \& Taussky 1945), using 1/12 $\mathrm{N}$ sulphuric acid and $10 \%$ sodium wolframate for precipitation of the proteins, seems to provide a good material for determination of creatinine without the influence of other chromogenic substances.

The urea clearance in pigs is $12 \mathrm{ml} / \mathrm{min} . / 10 \mathrm{~kg}$ or $34 \mathrm{ml} /$ min./100 $\mathrm{g}$ kidney, which is of the same order of magnitude as found in cows (Poulsen 1956) and horses (Knudsen). The urea clearance seems to be constant at urine flows of 0.07 to $0.32 \mathrm{ml} /$ $\min . / 10 \mathrm{~kg}$ and is, on an average, $60 \%$ of the inulin clearance. A similar relationship between urea clearance and filtration clearance has been found in man (Iversen et al. 1946), cows (Poulsen 1956) and horses (Knudsen) at urine flows of more than $0.2 \mathrm{ml} / \mathrm{min} . / 10 \mathrm{~kg}$. Thus the "augmentation limit" in pigs seems to obtain at a lower urine flow than is the case in man and other animals.

At low plasma concentrations $(<20 \mu \mathrm{g} / \mathrm{ml})$ the clearance of para-aminohippuric acid is 3 to 4 times greater than the filtration clearance, and the filtration fraction varies from 0.24 to 0.37 (average 0.33 ). The filtration fraction found in these experiments is slightly higher than the values stated by Munsick et al. and Ketz (1960a) for pigs, viz. 0.26 and 0.24 , respectively. In experiments on anaesthetized pigs weighing 10-25 kg Nielsen (1968) found clearances of inulin and PAH to be 36 and $121 \mathrm{ml} / \mathrm{min}$./ $10 \mathrm{~kg}$ b.wt., respectively. The filtration fraction was 0.24 . The fil- 
tration fraction is 0.16 to 0.20 in man and 0.20 to 0.30 in dogs (Pitts), while in horses, sheep and goats it is between 0.11 and 0.17 (Vogel 1962).

The percentage extraction of PAH has been found to be $87 \%$, which corresponds to the value found in man, while in dogs it is 75 to $80 \%$ (Pitts).

The average total renal blood flow is $133 \mathrm{ml} / \mathrm{min} . / 10 \mathrm{~kg}$ body weight, varying from 115 to $160 \mathrm{ml} / \mathrm{min} . / 10 \mathrm{~kg}$, or from 300 to $440 \mathrm{ml} / \mathrm{min} . / 100 \mathrm{~g}$ kidney. This is of the same order of magnitude as in man (Pitts). Ketz (1960a) reports that the effective renal blood flow in pigs weighing $51 \mathrm{~kg}$ is $421 \mathrm{ml} / \mathrm{min} . / \mathrm{m}^{2}$ surface. However, Ketz (1960a) calculated the renal blood flow according to the formula

$$
\mathrm{RBF}=\frac{(100+\text { haematocrit } \%) \times \mathrm{RPF}}{100}
$$

while that used in the present study is

$$
\mathrm{RBF}=\frac{\mathrm{RPF} \times 100}{100-\text { haematocrit } \%}
$$

If this latter formula is used to calculate the effective renal blood flow in Ketz's work (1960a), a figure of $514 \mathrm{ml} / \mathrm{min} . / \mathrm{m}^{2}$ surface is obtained instead of 421 . If this effective renal blood flow is converted to total renal blood flow per $10 \mathrm{~kg}$ body weight, since a pig weighing $51 \mathrm{~kg}$ has a surface of $1.35 \mathrm{~m}^{2}$, and according to our findings the extraction percentage for PAH is 87 , a figure of $157 \mathrm{ml} / \mathrm{min} . / 10 \mathrm{~kg}$ is obtained. This corresponds to the highest values in the present study (Table 5).

The maximal tubular excretion of PAH found, viz. $23 \mathrm{mg} /$ $\min . / 10 \mathrm{~kg}$, is slightly lower than that stated by Munsick et al., viz. $31 \mathrm{mg} / \mathrm{min} . / 10 \mathrm{~kg}$ ( 2 miniature pigs). For the sake of comparison, it can be mentioned that the Tm of $\mathrm{PAH}$ in man and dogs is generally given as 12 and $10 \mathrm{mg} / \mathrm{min} . / 10 \mathrm{~kg}$ body weight, respectively (Smith 1956). It can be added that in some cases inulin clearance is decreased considerably during loading with PAH. Similar observations have been made previously by other workers (see Smith 1951).

The clearance values for sodium, potassium and chloride are about the same as Ketz (1960a) found in experiments on pigs weighing 25 and $50 \mathrm{~kg}$. 


\section{REFERENCES}

Bonsnes, R. W. \& H. H. Taussky: On the colorimetric determination of creatinine by the Jaffe reaction. J. biol. Chem. 1945, 158, 581591.

Bratton, A. C. \& E. K. Marshall: A new coupling component for sulfanilamide determination. J. biol. Chem. 1939, 128, 537-550.

Brun, C.: In Iversen, P., T. Bjering \& J. Bing: De medicinske nyrelidelser. 2. udg., København 1946, pp. 83-85.

Conway, E. J.: Microdiffusion analysis and volumetric error. 3rd Ed., London 1950, p. 152.

Dalgaard-Mikkelsen, S., E. Poulsen \& B. Simesen: Sulfadimidin og sulfatiazol til ungsvin. Nord. Vet.-Med. 1953, 5, 965-981.

Iversen, P., T. Bjering \& J. Bing: De medicinske nyrelidelser. 2. udg., København 1946, pp. 78--82.

Ketz, H.-A.: Untersuchungen zur Nierenfunktion und renalen Elektrolytausscheidung beim Schwein. Arch. exp. Vet.-Med. 1960a, 14, $290-305$.

Ketz, H.-A.: Vergleichende Betrachtungen zur Nierenfunktion bei den Haustieren. Zbl. Vet.-Med. 1960b, 7, 411-419.

Knudsen, E.: Renal clearance studies on the horse I. Acta vet. scand. $1959,1,52-66$.

Munsick, R. A., W. H. Sawyer \& H. B. van Dyke: The antidiuretic potency of arginine and lysine vasopressins in the pig with observations on porcine renal function. Endocrinology 1958, $63,688-693$.

Nielsen, Ole E.: Den renale kaliumudskillelse. København 1968, pp. $31-37$.

Pitts, R. F.: Physiology of the kidney and body fluids. Chicago 1965, pp. 64-65 and 132-133.

Poulsen, E.: Renale clearanceundersøgelser hos køer. København 1956, pp. $42-48$ and $62-65$.

Poulsen, E.: Renal clearance in the cow. Royal Veterinary and Agricultural College, Yearbook, Copenhagen 1957, pp. 97-126.

Schales, O. \& S. S. Schales: A simple and accurate method for the determination of chloride in biological fluids. J. biol. Chem. 1941, 140, 879-884.

Smith, H. W.: The kidney. New York 1951, p. 159.

Smith, H. W.: Principles of renal physiology. New York 1956, pp. 32, 102 and 104.

Vogel, G.: Vergleichende Untersuchungen zur Kalium-Exkretion der Nieren verschiedener Haussäugetiere. Pflüg. Arch. ges. Physiol. $1959 \mathrm{a}, 269,339-343$.

Vogel, G.: Zur Bestimmung von glomerulärer Filtrationsrate und filtrierender Fläche in der Niere einiger Haussäugetiere. Pflüg. Arch. ges. Physiol. 1959b, 269, 264-269.

Vogel, G.: Beiträge zur Kenntnis der Nierenphysiologie einiger Haussäugetiere. Beiheft 3, Zbl. Vet.-Med. 1962, p. 26. 


\section{SUMMARY}

Renal clearance studies were performed on 31 unanaesthetized pigs weighing from 28 to $123 \mathrm{~kg}$. These included simultaneous determination of clearance, at constant plasma concentrations, of inulin, endogenous creatinine, urea, para-aminohippuric acid, sodium, potassium and chloride. The clearances found, calculated per $10 \mathrm{~kg}$ body weight, are as follows: inulin $21 \mathrm{ml} / \mathrm{min}$, endogenous creatinine 22 $\mathrm{ml} / \mathrm{min}$., urea (max. clearance) $12 \mathrm{ml} / \mathrm{min}$., para-aminohippuric acid $64 \mathrm{ml} / \mathrm{min}$., sodium $0.015 \mathrm{ml} / \mathrm{min}$., potassium $2.8 \mathrm{ml} / \mathrm{min}$. and chloride $0.11 \mathrm{ml} / \mathrm{min}$.

It was also shown that inulin is a filtration substance in pigs, since clearance is independent of the rate of urine flow from 0.07 to 1.91 $\mathrm{ml} / \mathrm{min} . / 10 \mathrm{~kg}$, and of variations in inulin concentration in plasma from 40 to $1900 \mu \mathrm{g} / \mathrm{ml}$.

The average ratio between clearance of inulin and endogenous creatinine was 1.0, varying from 0.8 to 1.2 . The filtration fraction $\left(\mathrm{C}_{\mathrm{In}} / \mathrm{C}_{\mathrm{PAH}}\right)$ was determined at 0.33 and the max. tubular excretion of $\mathrm{PAH}$ at $23 \mathrm{mg} / \mathrm{min} . / 10 \mathrm{~kg}$. The percentage extraction of $\mathrm{PAH}$, determined on anaesthetized pigs, was found to be $87 \%$. The total renal blood flow was calculated to be $133 \mathrm{ml} / \mathrm{min} . / 10 \mathrm{~kg}$ body weight or $363 \mathrm{ml} / \mathrm{min} . / 100 \mathrm{~g}$ kidney.

\section{ZUSAMMENFASSUNG}

Renale Clearanceuntersuchungen an Schueinen. Inulin, endogenes Kreatinin, Harnstoff, Para-Aminohippursäure, Natrium, Kalium und Chlorid.

Es wurden renale Clearanceuntersuchungen an 31 nicht anästhesierten Schweinen mit einem Körpergewicht von 28 bis $123 \mathrm{~kg}$ vorgenommen. Die Untersuchungen umfassten simultane Bestimmung der Clearance bei konstanter Plasmakonzentration von Inulin, endogenem Kreatinin, Harnstoff, Para-Aminohippursäure, Natrium, Kalium und Chlorid. Folgende Werte berechnet pro $10 \mathrm{~kg}$ Körpergewicht wurden gefunden: Inulinclearance $21 \mathrm{ml} / \mathrm{Min}$., endogene Kreatininclearance $22 \mathrm{ml} /$ Min., Harnstoff-Maximalclearance $12 \mathrm{ml} /$ Min., Para-Aminohippursäureclearance $64 \mathrm{ml} / \mathrm{Min}$. und Clearance für Natrium, Kalium und Chlorid 0,015, 2,8 bzw. 0,11 ml/Min.

Ausserdem wurde gezeigt, dass Inulin bei Schweinen ein Filtrationsstoff ist, da die Clearance unabhängig von Diuresevariationen von 0,07 bis $1,91 \mathrm{ml} / \mathrm{Min} . / 10 \mathrm{~kg}$ sowie von Variationen in der Inulinkonzentration im Plasma von 40 bis $1900 \mu \mathrm{g} / \mathrm{ml}$ ist.

Das Verhältnis zwischen der Inulinclearance und der Clearance des endogenen Kreatinins war durchschnittlich 1,0 variierend von 0,8 bis 1,2. Die Filtrationsfraktion $\left(\mathrm{C}_{\mathrm{In}} / \mathrm{C}_{\mathrm{PAH}}\right)$ wurde zu 0,33 bestimmt. Die maximale tubulare Exkretion von PAH war $23 \mathrm{mg} / \mathrm{Min} . / 10 \mathrm{~kg}$. Der Extraktionsprozent für $\mathrm{PAH}$, der an anästhesierten Schweinen bestimmt wurde, betrug $87 \%$. Die totale renale Blutdurchströmung wurde zu $133 \mathrm{ml} / \mathrm{Min} . / 10 \mathrm{~kg}$ Körpergewicht oder $363 \mathrm{ml} / \mathrm{Min} . / 100 \mathrm{~g}$ Niere berechnet. 


\section{SAMMENDRAG}

Renale clearanceunders $\phi g e l s e r$ på svin. Inulin, endogen kreatinin, urinstof, para-aminohippursyre, natrium, kalium og klorid.

Der er udf $\varnothing$ rt renale clearanceunders $\varnothing$ gelser på 31 ikke anæsteserede svin med en legemsvægt fra 28 til $123 \mathrm{~kg}$. Unders $\varnothing$ gelserne omfatter simultan bestemmelse af clearance ved konstant plasmakoncentration for inulin, endogen kreatinin, urinstof, para-aminohippursyre, natrium, kalium og klorid. Der fandtes følgende værdier beregnet pr. $10 \mathrm{~kg}$ legemsvægt: Inulinclearance $21 \mathrm{ml} / \mathrm{min}$., endogen kreatininclearance $22 \mathrm{ml} / \mathrm{min}$., urinstof-maksimal-clearance $12 \mathrm{ml} / \mathrm{min}$., paraaminohippursyreclearance $64 \mathrm{ml} / \mathrm{min}$. og clearance for natrium, kalium og klorid henholdsvis $0,015,2,8$ og $0,11 \mathrm{ml} / \mathrm{min}$.

Det er desuden vist, at inulin hos svin er et filtrationsstof, idet clearance er uafhængig af diuresevariationer fra $0,07-1,91 \mathrm{ml} / \mathrm{min}$./ $10 \mathrm{~kg}$ og af variationer $\mathrm{i}$ inulinkoncentrationen i plasma fra 40 til 1900 $\mu \mathrm{g} / \mathrm{ml}$.

Forholdet mellem inulinclearance og clearance for endogen kreatinin var i gennemsnit 1,0 varierende fra 0,8 til 1,2. Filtrationsfraktionen $\left(\mathrm{C}_{\text {In }} / \mathrm{C}_{\mathrm{PAH}}\right)$ blev bestemt til 0,33 , og den maximale tubulære ekskretion af PAH var $23 \mathrm{mg} / \mathrm{min} . / 10 \mathrm{~kg}$. Ekstraktionsprocenten for $\mathrm{PAH}$, der bestemtes på anæsteserede svin, blev fundet til $87 \%$. Det totale renale blood flow er beregnet til $133 \mathrm{ml} / \mathrm{min} . / 10 \mathrm{~kg}$ lgv. eller $363 \mathrm{ml} / \mathrm{min} . / 100 \mathrm{~g}$ nyre.

(Received March 7, 1968). 